\title{
In vitro conservation of ornamental plants ${ }^{(1)}$
}

\author{
DIOGO PEDROSA CORREAA DA SILVA ${ }^{\left(2^{*}\right)}$, ELIF AYLIN OZUDOGRU ${ }^{(3)}$, \\ MICHELE VALQUÍRIA DOS REIS ${ }^{(4)}$, MAURIZIO LAMBARDI ${ }^{(3)}$
}

\begin{abstract}
The market of flowers and ornamental plants is dependent on the diversification of species and the availability of high quality propagation materials. Actually, in vitro culture techniques performance a prominent role in the multiplication and maintenance of commercially propagated ornamental plant species, and are promising for the production of thousands of high quality plants in relatively short term. In addition, when market demand for a particular species is low or zero in a specific period of the year, in vitro culture techniques allow the conservation of cultures under aseptic conditions, by Slow Growth Storage (SGS), from a few weeks to one year (or more), without affecting their viability and potential regrowth. This can be achieved by modifying the constitution of the culture medium and the maintenance conditions of in vitro cultures. Obviously, the success of the technique depends on greatly on the physiological characteristics of the species to be conserved, as well. Once a SGS protocol is optimized, the expenses labor, the possibility of contamination and the probability of somaclonal variation can be reduced markedly.
\end{abstract}

Keywords: Flowers, Shoot cultures, Slow Growth Storage

\section{INTRODUCTION}

The ornamental plant industry is expanding every year around the world (BOTELHO et al., 2015). This is due to the availability of high quality regenerative and phytosanitary propagation materials, allowing the diversification of ornamental plants used in the various segments of the business chain, as garden plants, cut flowers and foliage, dried flowers, edible flowers, and others. The use of biotechnological tools, such as in vitro culture techniques, is, undoubtedly, one of the key components that allowed the increase of this diversification of quality materials available to the actual market of ornamental plants.

Recent developments in in vitro culture techniques allow the medium-term storage of plants under aseptic conditions, without requiring any periodic operation, such as subculturing to fresh medium. The storage is done by reducing the metabolism of plants, and although highly species-specific, it can be extended for several months or even to several years. The induction of a slower metabolism in the plants allows the reduction of the frequency of periodic subcultures, therefore it also reduces labor and costs, and the risk of contamination during the subcultures. Plant metabolism may be reduced by (i) reduction of temperature and / or light intensity, (ii) addition of osmotic compounds such as mannitol or sucrose, thus reducing the availability of water and (iii) addition of growth retardants in storage medium, especially inhibitors of gibberellin biosynthesis (GROUT, 1995; RADEMACHER, 2000; CASTRO and HILHORST,
2004; SILVA and SCHERWINSKI-PEREIRA, 2011). These approaches can be applied alone, or in combination. For instance, the reduction of temperature, in combination with reduced or absence of light intensity is the one mostly applied. These factors reduce significantly the respiration, water loss, and ethylene production, and thus the cell metabolism and growth (OZUDOGRU et al., 2010). The optimized conservation protocols also allow an immediate access to germplasm of interest when the market request arrives again and maintain genetic diversity without compromising its stability (ENGELMANN, 2004; SHIBLI et al., 2006; RAI et al., 2009). It should be noted that, also the age, size and physiological status of the plant material affect markedly the success and the maximum storage time of SGS (ORLIKOWSKA, 1992).

Although routine use of this technique is still limited, examples are increasing where in vitro conservation is used both in research laboratories and in ornamental plant biofactories. For instance, the germplasm conservation of native species with high commercial potential as ornamental, or for the alimentation and pharmacological use, has been used to preserve genetic variability and allowed the study of its properties in a controlled environment through the use of in vitro culture techniques (FORD-LLOYD and JACKSON, 1991; VILLALOBOS et al., 1991; BERTONI et al., 2010). The establishment of an in vitro protocol for the conservation of a wild species allowed the creation of reference databases for future studies of other species (CORDEIRO et al., 2012).

\footnotetext{
DOI: http://dx.doi.org/10.14295/oh.v24i1.1163

(1) Received in 15/01/2017 and accepted in 05/03/2018

(2) Universidade Federal de Lavras, Departamento de Agricultura, Lavras-MG, Brazil. *Corresponding author: pedrosacorrea@yahoo.com.br

(3) CNR-IVALSA, Trees and Timber Institute, Sesto Fiorentino (Florence), Italy.

(4) Universidade Federal de Lavras, Departamento de Biologia, Setor de Fisiologia Vegetal, Lavras-MG, Brazil.

Licensed by CC BY 4.0
} 
In vitro conservation can refer to medium- or long-term conservation. Long-term conservation of the germplasm is possible only through a technique called 'cryopreservation', where plant material is stored at ultra-low temperatures (usually of liquid nitrogen, at $-196^{\circ} \mathrm{C}$ ). This review, however, will deepen into the technique of Slow Growth Storage for the medium-term conservation of ornamental plants.

\section{SLOW GROWTH STORAGE OF ORNAMEN- TAL PLANTS}

The method of slow growth storage consists in decelerating or suppressing the the plants physiological metabolism. Differently of cryopreservation, in which for long periods, the plant material is stored at ultralow temperatures, suppressing growth, in order to avoid deterioration of plant (GROUT, 1995; SILVA and SCHERWINSKI-PEREIRA, 2011). This method has been used for conservation in short- and medium- term, mainly for meristems and/or shoot tips of several species. It consists in reduction of the growth and increase the intervals between the subcultures, without affecting significantly the viability of the explants (ENGELMANN, 2011).

This can be achieved modifying the potentially osmotic from the culture medium, thereby reducing the availability of water, or using plant growth retardants (especially inhibitors of gibberellin biosynthesis). It is also possible to reduce the light and temperature of the incubation room, in such a way as to achieve the minimum in vitro growth (RADEMACHER, 2000; CASTRO and HILHORST, 2004; SILVA and SCHERWINSKI-PEREIRA, 2011). However, the success of this technique depends greatly on physiological characteristics of the species to be conserved.

The use of low temperature $\left(04\right.$ to $\left.18^{\circ} \mathrm{C}\right)$ and nutrient medium supplementation with osmoregulators (sucrose for example) have been used to conserve explants for clonal propagation such as tubers, roots of fruit and ornamental species (OZUDOGRU et al., 2010).

Thus, a widely approach used has been the addition of osmotic agents and the reduction of temperature together, in which the species are maintained. The low temperature increases the transfer interval to new medium and often regardless of the type and concentration of carbohydrate used (LIMA-BRITO et al., 2011).

There are a few studies in Slow Growth Storage (SGS) of ornamental plants and most of them use temperature reduction to obtain slower rates of growth during the storage. The storage temperatures range from $2-6^{\circ} \mathrm{C}$ to $23-24^{\circ} \mathrm{C}$ especially for the species of tropical and subtropical climates (Table 1).

Table 1. Slow Growth Storage of ornamental plants

\begin{tabular}{|c|c|c|c|c|c|c|}
\hline Species & $\begin{array}{c}\text { Storage } \\
\text { Temp }\left({ }^{\circ} \mathbf{C}\right)\end{array}$ & $\begin{array}{l}\text { Storage Light/ } \\
\text { Radiance }\end{array}$ & $\begin{array}{c}\text { Storage } \\
\text { Period } \\
\text { (Months) }\end{array}$ & $\begin{array}{c}\text { Recovery } \\
(\%)\end{array}$ & $\begin{array}{l}\text { Explant } \\
\text { Type }\end{array}$ & References \\
\hline Acanthostachys strobilacea & 10 & $\begin{array}{c}12 \mathrm{~h} \\
\left(30 \mu \mathrm{mol} \mathrm{m} \mathrm{m}^{-2} \mathrm{~s}^{-1}\right)\end{array}$ & 3 & 100 & Seedling & $\begin{array}{l}\text { CARVALHO et } \\
\text { al, } 2014\end{array}$ \\
\hline Anthurium andreanum & $6-10$ & Darkness & 8 & 56 & $\begin{array}{l}\text { Shoot } \\
\text { cultures }\end{array}$ & $\begin{array}{l}\text { BENELLI et al., } \\
2012\end{array}$ \\
\hline Camellia japonica & 4 & Darkness & 2 & 30 & $\begin{array}{l}\text { Synthetic } \\
\text { seeds }\end{array}$ & $\begin{array}{l}\text { JANEIRO et al. } \\
1997\end{array}$ \\
\hline $\begin{array}{c}\text { Camellia japonica (cv Alba } \\
\text { Plena) }\end{array}$ & $2-4$ & $\begin{array}{c}16 \mathrm{~h} \\
\left(8 \mu \mathrm{mol} \mathrm{m} \mathrm{m}^{-2} \mathrm{~s}^{-1}\right)\end{array}$ & 12 & 100 & $\begin{array}{l}\text { Shoot } \\
\text { cultures }\end{array}$ & $\begin{array}{l}\text { BALLESTER et } \\
\text { al., } 1997\end{array}$ \\
\hline $\begin{array}{c}\text { Camellia reticulata }(\mathrm{cv} \\
\text { Mouchang) }\end{array}$ & $2-4$ & $\begin{array}{c}16 \mathrm{~h} \\
\left(8 \mu \mathrm{mol} \mathrm{m} \mathrm{m}^{-2} \mathrm{~s}^{-1}\right)\end{array}$ & 12 & 100 & $\begin{array}{l}\text { Shoot } \\
\text { cultures }\end{array}$ & $\begin{array}{l}\text { BALLESTER et } \\
\text { al., } 1997\end{array}$ \\
\hline Cedrela fissilis & 25 & $\begin{array}{c}16 \mathrm{~h} \\
\left(20-25 \mu \mathrm{mol} \mathrm{m}{ }^{-2} \mathrm{~s}^{-1}\right)\end{array}$ & 9 & 8 & $\begin{array}{l}\text { Synthetic } \\
\text { seeds }\end{array}$ & $\begin{array}{l}\text { NUNES et al., } \\
2003\end{array}$ \\
\hline Deutzia scabra & $24-4$ & Darkness & 12 & 96.67 & $\begin{array}{l}\text { Shoot } \\
\text { cultures }\end{array}$ & $\begin{array}{l}\text { GABR and } \\
\text { SAYED, } 2010\end{array}$ \\
\hline Dianthus ingoldbyi & 4 & Darkness & 6 & 58 & $\begin{array}{l}\text { Shoot } \\
\text { cultures }\end{array}$ & $\begin{array}{l}\text { ARDA et al., } \\
2016\end{array}$ \\
\hline Drimiopsis kirkii & 15 & $16 \mathrm{~h}(3000 \mathrm{lux})$ & 4 & 64.4 & $\begin{array}{l}\text { Synthetic } \\
\text { seeds }\end{array}$ & $\begin{array}{l}\text { HAQUE and } \\
\text { GHOSH, } 2014\end{array}$ \\
\hline Epidendrum chlorocorymbos & 23 & $16 \mathrm{~h}(1500 \mathrm{lux})$ & 6 & 100 & Seedling & $\begin{array}{l}\text { LOPEZ-PUC et } \\
\text { al., } 2013\end{array}$ \\
\hline Gerbera (cv Marleen) & 4 & Darkness & 3 & 100 & $\begin{array}{l}\text { Shoot } \\
\text { cultures }\end{array}$ & $\begin{array}{l}\text { HEMPEL and } \\
\text { HEMPEL, } 1987\end{array}$ \\
\hline
\end{tabular}


Table 1. cont.

\begin{tabular}{|c|c|c|c|c|c|c|}
\hline Heliconia champneiana & 25 & 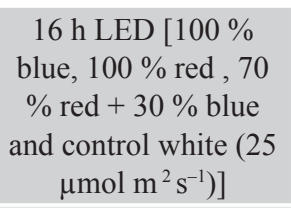 & 3 & 100 & Seedling & $\begin{array}{l}\text { RODRIGUES et } \\
\text { al., } 2018\end{array}$ \\
\hline $\begin{array}{l}\text { Hibiscus moscheutos } \\
\text { (cv Lord Baltimore) }\end{array}$ & 5 & Darkness & 19.5 & 80 & $\begin{array}{l}\text { Synthetic } \\
\text { seeds }\end{array}$ & $\begin{array}{l}\text { WEST et al, } \\
2006\end{array}$ \\
\hline Humulus spp. & 4 & $12 \mathrm{~h}\left(3 \mu \mathrm{mol} \mathrm{m}{ }^{-2} \mathrm{~s}^{-1}\right)$ & 36 & $\mathrm{NR}^{*}$ & $\begin{array}{l}\text { Shoot } \\
\text { cultures }\end{array}$ & $\begin{array}{l}\text { REED et al., } \\
2003\end{array}$ \\
\hline Lilium longiflorum & 4 & Darkness & 6 & 92 & $\begin{array}{l}\text { Synthetic } \\
\text { seeds }\end{array}$ & $\begin{array}{l}\text { STANDARDI et } \\
\text { al,1995 }\end{array}$ \\
\hline $\begin{array}{l}\text { Metrosideros excelsa Soland. } \\
\text { ex Gaertn. }\end{array}$ & $4-10$ & Darkness & 4 & 58 & $\begin{array}{l}\text { Synthetic } \\
\text { seeds }\end{array}$ & $\begin{array}{l}\text { BENELLI et al., } \\
2017\end{array}$ \\
\hline Morus spp & 5 & Darkness & 3 & 18 & $\begin{array}{l}\text { Synthetic } \\
\text { seeds }\end{array}$ & $\begin{array}{l}\text { PATTNAIK and } \\
\text { CHAND, } 2000\end{array}$ \\
\hline Nandina domestica & $4-8$ & Darkness & 6 & 100 & $\begin{array}{l}\text { Shoot } \\
\text { cultures }\end{array}$ & $\begin{array}{c}\text { OZUDOGRU et } \\
\text { al., } 2013\end{array}$ \\
\hline Nerium oleander & 4 & Darkness & 3 & 30 & $\begin{array}{l}\text { Synthetic } \\
\text { seeds }\end{array}$ & $\begin{array}{l}\text { OZDEN-TO- } \\
\text { KATLI et al., } \\
2008\end{array}$ \\
\hline Paulownia elongatee & 4 & Darkness & 2 & 32 & $\begin{array}{l}\text { Synthetic } \\
\text { seeds }\end{array}$ & $\begin{array}{c}\text { IPEKCI and } \\
\text { GOZUKIRMIZI, } \\
2003\end{array}$ \\
\hline Photinia $\times$ fraseri Dress & $4-10$ & Darkness & 4 & 65 & $\begin{array}{l}\text { Synthetic } \\
\text { seeds }\end{array}$ & $\begin{array}{l}\text { BENELLI et al., } \\
2017\end{array}$ \\
\hline Photinia fraseri & 4 & Darkness & 3 & 91 & $\begin{array}{l}\text { Synthetic } \\
\text { seeds }\end{array}$ & $\begin{array}{l}\text { OZDEN- } \\
\text { TOKATLI et al., } \\
2008\end{array}$ \\
\hline Polygala myrtifolia & $4-10$ & Darkness & 8 & 68.8 & $\begin{array}{l}\text { Synthetic } \\
\text { seeds }\end{array}$ & $\begin{array}{l}\text { BENELLI et al., } \\
2017\end{array}$ \\
\hline Ranunculus asiaticus & $4-10$ & Darkness & 9 & 100 & $\begin{array}{l}\text { Shoot } \\
\text { cultures }\end{array}$ & $\begin{array}{l}\text { BENELLI et al., } \\
2012\end{array}$ \\
\hline Rosa cvs & 4 & Darkness & 6 & $>80$ & $\begin{array}{l}\text { Shoot } \\
\text { cultures }\end{array}$ & $\begin{array}{l}\text { PREVIATI et al., } \\
2008\end{array}$ \\
\hline Rosa hybrida 'King's Ransom & 4 & Darkness & 1.33 & 30 & $\begin{array}{l}\text { Synthetic } \\
\text { seeds }\end{array}$ & $\begin{array}{l}\text { JAYASREE and } \\
\text { DEVI, } 1997\end{array}$ \\
\hline Splachnum ampullaceum & 5 & Darkness & 30 & 50 & $\begin{array}{l}\text { Synthetic } \\
\text { seeds }\end{array}$ & $\begin{array}{l}\text { MALLÓN et al., } \\
2007\end{array}$ \\
\hline Syringa vulgaris & 5 & Darkness & 1.5 & 83 & $\begin{array}{l}\text { Synthetic } \\
\text { seeds }\end{array}$ & $\begin{array}{l}\text { REFOUVELET } \\
\text { et al., } 1998\end{array}$ \\
\hline Turbinicarpus & 4 & $\begin{array}{l}\text { Continuous light } \\
\left(54 \mu \mathrm{mol} \mathrm{m}{ }^{-2} \mathrm{~s}^{-1}\right)\end{array}$ & 12 & $\mathrm{NR}^{*}$ & $\begin{array}{l}\text { Shoot } \\
\text { cultures }\end{array}$ & $\begin{array}{l}\text { BALCH et al., } \\
2012\end{array}$ \\
\hline Vriesea inflata & 15 & $\begin{array}{c}12 \mathrm{~h} \\
\left(55 \mu \mathrm{mol} \mathrm{m} \mathrm{m}^{-2} \mathrm{~s}^{-1}\right)\end{array}$ & 24 & 100 & Seedling & $\begin{array}{l}\text { PEDROSO et } \\
\text { al., } 2010\end{array}$ \\
\hline
\end{tabular}

*NR: not reported

Storage under dark conditions is more commonly applied approach for conservation of ornamental plants, however shorter photoperiods (i.e., 8-12 h), instead of $16 \mathrm{~h}$ that is commonly used as standard in in vitro plant cultivation (e.g., REED et al, 2003; PEDROSO et al., 2010; CARVALHO et al., 2014), or the use of low light intensities (3 to $8 \mu \mathrm{mol} \mathrm{m} \mathrm{m}^{-2}$ $\left.\mathrm{s}^{-1}\right)$ have also been shown to be effective in reducing plant metabolism (e.g., BALLESTER et al., 1997; REED et al., 2003). Rodrigues et al. (2018) tested different light spectrum of LED light to reduce the plant development.
Another strategy for SGS is the use of substances such as sucrose, mannitol, and sorbitol that reduce the osmotic potential of the culture medium (GROUT, 1991). For example, the use of mannitol provided 4 month-storage of Epidendrum chlorocorymbos (LOPES-PUC, 2013). In Nandina doméstica, storage up to 6 months was possible using a relatively high concentration of sucrose $\left(60 \mathrm{~g} \mathrm{~L}^{-1}\right.$ instead of $30 \mathrm{~g} \mathrm{~L}^{-1}$ ) (OZUDOGRU et al., 2013).

Decreasing the salt concentration of the culture medium, in other words reducing the absorption of nutrients 
responsible for plant growth and development, can also be used as a strategy to reduce plant growth during the SGS (ENGELMANN, 1991). Indeed, for Epidendrum chlorocorymbos, reducing the salts of the culture medium to $50 \%$ provided a better SGS, being able to store for 4 months (LOPES-PUC, 2013).

Regarding the maximum storage time, Hibiscus moscheutos was stored for approximately 20 months (WEST et al., 2006) and Splachnum ampullaceum for 30 months (MALLÓN et al., 2007). Reed et al. (2003) reported the possibility of storing Humulus spp at low temperature for up to 3 years.

The type of the culture container to be used in storage is another important factor to be taken into account in SGS (OZUDOGRU et al., 2010). For instance, in Ger- bera it was observed that when larger pots were used, greater rooting and survival rates were obtained at the end of 3 months compared to the smaller pots (HEMPEL and HEMPEL, 1987).

For in vitro conservation of Nandina domestica, effects of different storage temperatures $\left(4\right.$ and $\left.8^{\circ} \mathrm{C}\right)$ in dark and different concentrations of sucrose $\left(30,45,60 \mathrm{~g} \mathrm{~L}^{-1}\right)$ in the storage medium were evaluated (OZUDOGRU et al., 2013). The results showed that the plants had a maximum survival $(100 \%)$ after 6 months when they were stored at $8^{\circ} \mathrm{C}$ in the storage medium containing the highest concentration $\left(60 \mathrm{~g} \mathrm{~L}^{-1}\right)$ of sucrose. On the contrary, storage at $4{ }^{\circ} \mathrm{C}$ in the medium containing $30 \mathrm{~g} \mathrm{~L}^{-1}$ sucrose provided the lowest $(75 \%)$ survival rate after 6-month storage (Figure 1).
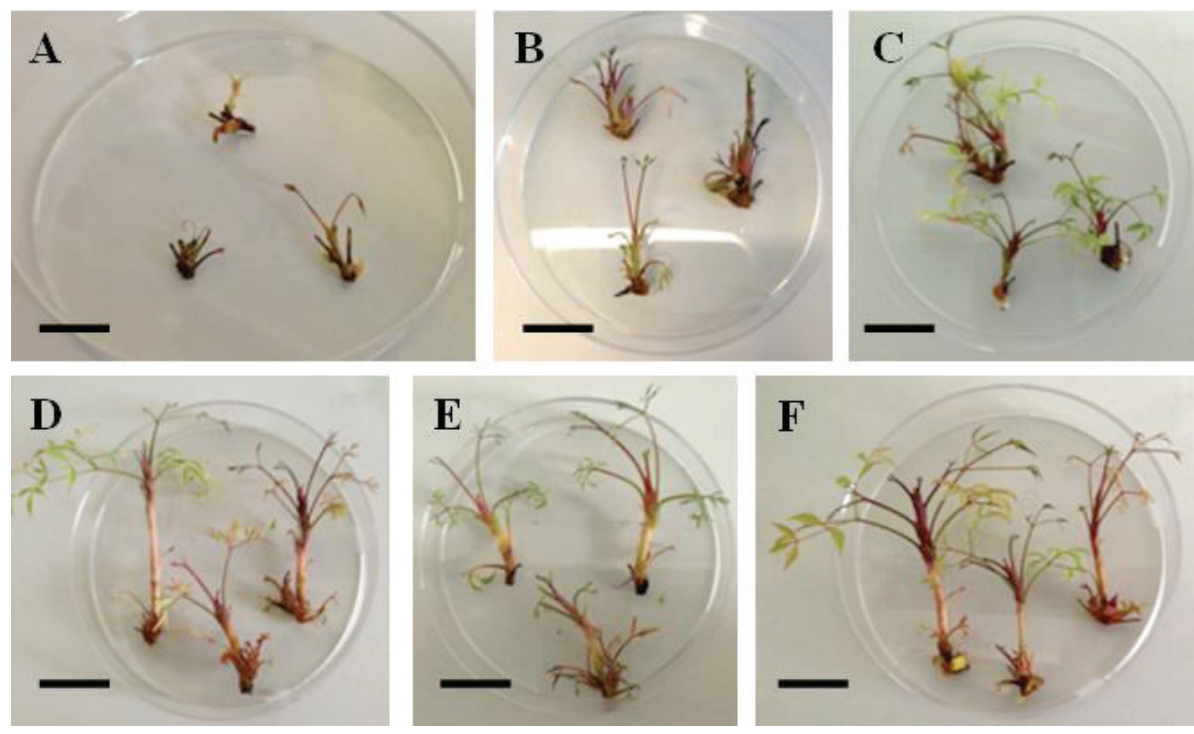

Figure 1. In vitro conservation of $N$. domestica by slow growth storage. Shoot recovery following 6 months of conservation at $4^{\circ} \mathrm{C}$ in darkness on storage medium containing $30(\mathrm{~A}), 45(\mathrm{~B})$ or $60 \mathrm{~g} \mathrm{~L}^{-1}(\mathrm{C})$ sucrose, or at $8{ }^{\circ} \mathrm{C}$ in darkness on 30 (D), 45 (E) or $60 \mathrm{~g} \mathrm{~L}^{-1}$ (F) sucrose. A, bar $15 \mathrm{~mm}$; B-F, bar $20 \mathrm{~mm}$ (OZUDOGRU et al., 2013).

Although only a limited number of studies use an in vitro conservation of ornamental species, the development of the technique, such as the use of new tools for the reduction of plant metabolic, can lead to an increase in the number of species conserved using the Slow Growth Storage technique.

\section{CONCLUSIONS}

In recent years, great progress has been observed in the development of new propagation and conservation techniques for ornamental species, especially in the area of slow growth, thus demonstrating a market increase in the use of these biotechnological advances. But it is important to emphasize that the technique of slow growth storage is one of the complementary alternatives for the conservation of ornamental plants, without taking away the importance of the other forms of conservation like the conservation in situ or ex situ.

\section{ACKNOWLEDGEMENTS}

To the National Council for Scientific and Technological Development (CNPq), the Coordination for the Improvement of Higher Education Personnel (CAPES) and the Research Support Foundation of the State of Minas Gerais (FAPEMIG) for the financial support of this study.

\section{AUTHORS CONTRIBUTIONS}

All authors: writing and proofreading the text. 


\section{REFERENCES}

ARDA, H.; DAYAN, S.; KARTAL, C.; GÜLER, N. In vitro conservation of critically endangered Dianthus ingoldbyi Turrill under slow growth conditions. Trakya University Journal of Natural Sciences, v.17, p. 47-54, 2016.

BALCH, E.P.M.; REYES, M.E.P.; CARRILLO, M.A.L.R. In vitro conservation of Turbinicarpus (cactaceae) under slow growth conditions. Haseltonia, v. 17p. 51-57, 2012. https://doi.org/10.2985/1070-0048-17.1.6

BALLESTER, A.; JANEIRO, L.V.; VIEITEZ, A.M. Cold storage of shoot cultures and alginate encapsulation of shoot tips of Camellia japonica L. and Camellia reticulata Lindley. Scientia Horticulturae, v.71, p.67-78, 1997. DOI: https://doi.org/10.1016/S0304-4238(97)00074-5

BENELLI, C.; OZUDOGRU, E.A.; LAMBARDI, M.; DRADI, G. In vitro conservation of ornamental plants by slow growth storage. Acta Horticulturae, v. 961, p.89-93, 2012. DOI: https://doi.org/10.17660/ActaHortic.2012.961.8

BENELLI, C.; MICHELI, M; CARLO, A. An improved encapsulation protocol for regrowth and conservation of four ornamental species. Acta Societatis Botanicorum Poloniae, v.86, p1-12, 2017. DOI: https://doi.org/10.5586/asbp.3559

BERTONI, B.W.; SOUZA, A.V.; BIONDO, R.; FRANÇA, S.C.; TELLES, M.P.C.; PEREIRA, A.M.S. Genetic diversity among natural populations of Mandevilla velutina. Horticultura Brasileira, v.28, p.209-213. 2010. https://dx.doi.org/10.1590/S0102-05362010000200012

BOTELHO, F.B.S.; RODRIGUES, C.S.; BRUZI, A.T. Ornamental Plant Breeding. Ornamental Horticulture, v. 21, p. 9-16, 2015.

CARVALHO, V.; SANTOS, D.S.; NIEVOLA, C.C. In vitro storage under slow growth and ex vitro acclimatization of the ornamental bromeliad Acanthostachys strobilacea. South African Journal of Botany, v.92, p.39-43, 2014. DOI: https://doi.org/10.1016/j.sajb.2014.01.011

CASTRO, R.D.; HILHORST, H.W. Embebição e reativação do metabolismo. FERREIRA, A.G.; BORGHETTI, F. (Orgs.). Germinação: do básico ao aplicado. Porto Alegre: Artmed, 2004. p.149-162.

CORDEIRO, S.Z.; SIMAS, N.K.; HENRIQUES, A.B; LAGE, C.L.S.; SATO, A. Micropropagation of Mandevilla moricandiana (A.DC.) Woodson. In Vitro Cellular: Development Biology - Plant. v.48, p.620-626. 2012. DOI: https://doi.org/10.1007/s11627-012-9477-5

ENGELMANN, F. In vitro conservation of tropical plant germplasm - a review. Euphytica. v.57, p.227-243 1991.
ENGELMANN, F. Plant cryopreservation: progress and prospects. In vitro Cellular: Developmental Biology Plant, v.40, p.427-433, 2004. DOI: https://doi.org/10.1079/ IVP2004541

FORD-LLOYD, B.V.; JACKSON, M.T. Biotechnology and methods of conservation of plant genetic resources. Journal of Biotechnology, v. 17, p. 247-256, 1991. https:// doi.org/10.1016/0168-1656(91)90015-N

GABR, A.M.M.; SAYED, S. S. Slow growth conservation and molecular characterization of Deutzia scabra Thunb. African Journal of Plant Science, v. 4, p. 409-416, 2010.

GROUT, B.W.V. Conservation in vitro. Acta Horticulturae, v. 289, p.171-178, 1991. DOI: https://doi.org/10.17660/ ActaHortic.1991.289.45

GROUT, B.W.W. Introduction to the in vitro preservation of plant cells, tissue and organs. In: GROUT, B.W.W. (ed.), Genetic preservation of plant cells in vitro. SpringerVerlag, Berlin Heidelberg, New York, 1995. p. 1-20.

HAQUE, S.K.M.; GHOSH, B. Somatic Embryogenesis and Synthetic Seed Production - a Biotechnological Approach for True-to-Type Propagation and In Vitro Conservation of an Ornamental Bulbaceous Plant Drimiopsis kirkii Baker. Applied Biochemistry and Biotechnology, v. 172, p. 40134024, 2014. DOI: https://oi.org/10.1007/s12010-014-0817-2

HEMPEL, T.; HEMPEL, M. Long-term storage of gerbera rooted in vitro. Acta Horticulturae. v. 212,p.360-360, 1987. DOI: https://doi.org/10.17660/ActaHortic.1987.212.53

IPEKCI, Z.; GOZUKIRMIZI, N. Direct somatic embryogenesis and synthetic seed production from Paulownia elongate. Plant Cell Reports, v.22, p.16-24, 2003. DOI: https://doi.org/10.1007/s00299-003-0650-5

JANEIRO, L.V.; BALLESTER, A.; VIEITEZ, A.M. In vitro response of encapsulated somatic embryos of camellia. Plant Cell, Tissue and Organ Culture, v. 51, p.119-125, 1997. DOI: https://doi.org/10.1023/A:1005958827202

JAYASREE, N.; DEVI, B.P. Production of synthetic seeds and plant regeneration in Rosa hybrid L. cv. King's Ransom. Indian Journal of Experimental Biology, v. 35, p.310-312, 1997.

LIMA-BRITO, A.; RESENDE, S.V.; LIMA, C.O.C.; ALVIM, B.M.; CARNEIRO, C.E.; SANTANA, J.R.F. In vitro morphogenesis of Syngonanthus mucugensis Giul. subsp. mucugensis. Ciência e Agrotecnologia, v. 35, p. 501-510, 2011. DOI: http://dx.doi.org/10.1590/S1413-70542011000300010

LOPEZ-PUC, G. An Effective in vitro slow growth protocol for conservation of the orchid Epidendrum chlorocorymbos Schltr. Tropical and Subtropical Agroecosystems, v. 16, p. 61-68, 2013. 
MALLÓN, R.; BARROS, P.; LUZARDO,A.; GONZÁLEZ, M.L. Encapsulation of moss buds: an efficient method for the in vitro conservation and regeneration of the endangered moss Splachnum ampullaceum. Plant Cell, Tissue and Organ Culture, v.88, p. 41-49, 2007. DOI: http://dx.doi. org/10.1007/s11240-006-9176-1

NUNES, E.D.C.; BENSON, E.E.; OLTRAMARI, A.C.; ARAUJO, P.S.; RIGHETTO, M.; VIANA, M. In vitro conservation of Cederla fissilis Vellozo (Meliaceae), a native tree of the Brazilian Atlantic Forest. Biodiversity and Conservation, v.12, p.837-848, 2003. DOI: http:// dx.doi.org/10.1023/A:1022492226341

ORLIKOWSKA, T. Effect of in vitro storage at $4^{\circ} \mathrm{C}$ on surviving and proliferation of two apple rootstocks. Plant Cell, Tissue and Organ Culture, v. 31, p1-7, 1992. DOI: http://dx.doi.org/10.1007/BF00043468

OZDEN-TOKATLI, Y.; DE CARLO, A.; GUMUSEL, F.; PIGNATTELLI, S.; LAMBARDI. M. Development of encapsulation techniques for the production and conservation of synthetic seeds in ornamental plants. Propagation of ornamental plants, v.8, p.17-22, 2008. DOI: http://dx.doi.org/10.5586/asbp.3559

OZUDOGRU, E.A.; PREVIATI, A.; LAMBARDI, M. In vitro conservation and cryopreservation of ornamental plants. JAIN, S.M.; OCHATT, S. J. (eds.), Protocols for in vitro Propagation of Ornamental Plants, Humana Press, Springer, New York, 2010, p. 303-324. DOI: https://doi. org/10.1007/978-1-60327-114-1_28

OZUDOGRU, E.A.; SILVA, D.P.C; KAYA, E.; DRADI, G.; PAIVA, R.; LAMBARDI, M. In vitro conservation and cryopreservation of Nandina domestica, an outdoor ornamental shrub. Notulae Botanicae Horti Agrobotanici Cluj-Napoca, v.41, p.638-645, 2013. DOI: http://dx.doi. org/10.15835/nbha4129335

PATTNAIK, S.; CHAND, P.K. Morphogenic response of the alginate-encapsulated axillary buds from in vitro shoot cultures of six mulberries Plant Cell, Tissue and Organ Culture, v. 60, p. 177-185, 2000. DOI: https://doi. org/10.1023/A:100642462

PEDROSO, A.N.V.; LAZARINI R. A.M.; TAMAKI, V.; NIEVOLA C.C. In vitro culture at low temperature and ex vitro acclimatization of Vriesea inflata an ornamental bromeliad. Brazilian Journal of Botany, v.33, n.3, p.407-414, 2010. DOI: http://dx.doi.org/10.1590/S010084042010000300004

PREVIATI, A.; BENELLI, C.; Da RE, F.; OZUDOGRU, A; LAMBARDI, M. Micropropagation and in vitro conservation of virus-free rose germplasm. Propagation of ornamental plants, v.8, p.93-98, 2008.
RADEMACHER, W. Growth retardants: effects on gibberellin biosynthesis and other metabolic pathways. Annual Review of Plant Physiology and Plant Molecular Biology, v. 51, p. 501-531, 2000. DOI: http://dx.doi. org/10.1146/annurev.arplant.51.1.501

RAI, M.K.; ASTHANA, P.; SINGH, S.K.; JAISWAL, V.S.; JAISWAL, U. The encapsulation technology in fruit plants: a review. Biotechnology Advances, v. 27, p. 671-679, 2009. DOI: https://doi.org/10.1016/j.biotechadv.2009.04.025

REED, B.M.; OKUT, N.; ACHINO, J.D.; NARVER, L.; DENOMA, J. Cold storage and cryopreservation of hops (Humulus L.) shoot cultures through application of standard protocols. CryoLetters, v.24, p.389-396, 2003.

REFOUVELET, E.; LE NOURS, S.; TALLON, C.; DAGUIN, F. A new method for in vitro propagation of lilac (Syringa vulgaris L.): Regrowth and storage conditions for axillary bud encapsulation in alginate beads, development of a preacclimatization stage. Scientia Horticulturae, v.74, p.233-241, 1998. DOI: https://doi.org/10.1016/S0304-4238(98)00088-0

RODRIGUES, P.H.V.; ARRUDA, F.; FORTI, V.A. Slowgrown in vitro conservation of Heliconia champneiana cv. Splash under different light spectra. Scientia Horticulturae, v.75, p163-166, 2018. DOI: http://dx.doi. org/10.1590/1678-992x-2016-0394

SHIBLI, R.A.; SHATNOWI, A.M.; SUBAIH, S.W.; AJLOUNI, M.M. In vitro conservation and cryopreservation of plant genetic resources: a review. World Journal of Agricultural Sciences, v. 2, p. 372-382, 2006.

SILVA, T.L.; SCHERWINSKI-PEREIRA, J.E. In Vitro Conservation of Piper aduncum and Piper hispidinervum under Slow-Growth Conditions. Pesquisa Agropecuária Brasileira, v. 46, p. 384-389, 2011. DOI: http://dx.doi. org/10.1590/S0100-204X2011000400007

STANDARDI A.; MICHELI, M.; PICCIONI, E. Incapsulamento in alginato di espianti micropropagati. Italus Hortus, v. 2, p.46-48, 1995.

VILLALOBOS, V.M.; FERREIRA, P.; MORA, A. The use of biotechnology in the conservation of tropical germplasm. Biotechnology Advances, v.9, p. 197-215, 1991. DOI: https://doi.org/10.1016/0734-9750(91)90004-F

WEST, T.P.; RAVINDRA, M.B.; PREECE, J.E. Encapsulation, cold storage, and growth of Hibiscus moscheutos nodal segments. Plant Cell, Tissue and Organ Culture, v. 87, p. 223-231, 2006. DOI: https://doi.org/10.1007/s11240-0069155-6 